\title{
SEROLOGIC EVIDENCE OF EQUINE H7 INFLUENZA VIRUS IN POLO HORSES IN NIGERIA
}

*OLUSA, T. A. O. ${ }^{1}$, ADEGUNWA, A. K. ${ }^{2}$, ADERONMU, A. A. ${ }^{2}$, ADEYEFA, C. A.O. ${ }^{2}$

1Department of Veterinary Medicine and Surgery, University of Agriculture, Abeokuta, Nigeria

2Department of Veterinary MedicineUniversity of Ibadan, Ibadan, Nigeria

*akin olusa@yahoo.co.uk

\section{INTRODUCTION}

Influenza is an acute epizootic viral respiratory disease that affects a wide variety of host species including humans, horses, pigs, sea mammals and birds. In horses, influenza virus is an important cause of infectious upper respiratory tract disease (IURTD) with serious economic losses particularly in the racing industry. The disease is characterized clinically by a frequent dry harsh cough, fever and serous nasal discharge, which later turn mucopurulent. The mode of spread is by aerosol with high morbidity and low to moderate mortality that could sometimes be very high in naïve equine populations. It is also associated with the destruction of epithelial cells lining the upper respiratory tracts, trachea and bronchi (Dulbecco \& Gunsbers, 1988).

The influenza viruses belong to the family Orthomyxoviridae of which there are five genera: influenza A, B and C, Thogovo and Isavirus (Palase \& Shaw, 2007). They are segmented, negative sense, single stranded RNA viruses classified in mammals and birds as serotypes $A, B$ and $C$ based on antigenic differences in their nucleoprotein (NP) and matrix (M1) protein (Akkina et al., 1991; Murphy \& Webster, 1996). Although influenza C viruses have been isolated from pigs in China, serotypes $B$ and $C$ usually infect humans only while influenza $A$ subtype viruses infect a wide variety of host species including man, horses, pigs, sea mammals and birds (Easterday, 1975; Guo et al., 1983). Two different subtypes of influenza A virus, equine-1 prototype [(A/equine/Praque/1/56 (H7N7)] and equine-2 prototype [(A/equine/Miami/1/ 63 (H3N8)] have been isolated from horses (Guo et al., 1992; 1995). Although both viruses produce similar disease signs in horses, the infection produced by equine-2 viruses is typically more severe because of the propensity of these viruses to invade the lower respiratory tract with the attendant secondary bacterial infection (Guo et al., 1995).

Transmission of influenza A viruses in mammals is by aerosols generated during coughing and sneezing but spread by direct contact is also possible (Knight, 1973; Webster et al., 1992; Wright et al., 2007). Immunity is subtype specific and depending on the extent of antigenic drift, immunity to natural infection has been estimated to last between 1 and 5 years while vaccination with current vaccines provides limited protection (Wood \& Mumford, 1992; Chamber, 1992; Adeyefa \& McCauley, 1994; Adeyefa \& McCauley, 1997a; Adeyefa et al.,; 1997b; Bayly, 1998). Diagnosis of equine influenza is based on traditional techniques such as virus isolation in embryonated eggs or tissue culture and or the detection of significant titre in paired serum samples (Anested \& Maagard, 1990), although molecular techniques are also currently used (Adeyefa et al., 1994; 1996b; 1997b; 2000). Enzyme Linked Immunosorbent Assay (ELISA) may also detect viral antigen in respiratory secretions (Anested \& Maagard, 1990; Adeyefa \& McCauley, 1997a; Adeyefa et al., 1997b).
Nigeria has an estimated horse population of 200, 000 (Bourn, 1992; FAOSTAT, 2008) and majority are use for playing the game of polo. Polo is a very organized sport in Nigeria and the Nigerian Polo Federation (NPF) governs its activities. In mid January 1991, an influenza outbreak caused by H3N8 subtype viruses was reported in Ibadan Polo Club stables during the annual polo tournament among horses from various polo clubs across the country (Adeyefa \& McCauley, 1994). Although equine-1 (H7N7) subtype has never been isolated in Nigeria nor anywhere in the world since 1979 (Webster, 1993) and influenza outbreak due to H3N8 subtype viruses has not been reported in the country since 1991, there have however been some reports of antibodies against $\mathrm{H} 7$ viruses in human, pig, avian and horses' sera in the country (Olaleye et al., 1990; Adeniji et al., 1993; Adeyefa, 1995). Moreover, importation of horses into Nigeria by the various polo clubs from all parts of the world especially Europe and South America has continued and transmission and spread of disease could be enhanced by congregation of horses during the annual polo tournaments and sales (Adeyefa \& McCauley, 1994; Olusa \& Adeyefa, 2009). The degree of antigenic variation within equine influenza viruses is of considerable interest (Adeyefa et al., 1996b, 2000). Since the current commercial vaccines which although trivalent have been reported to produce very short lived immunity in vaccinated horses (Chamber, 1992; Wood \& Mumford, 1992; Adeyefa \& McCauley, 1994; Adeyefa et al., 1997a) and several outbreak of diseases have occurred despite recent vaccination and strict quarantine measures (Lai et al., 1994). There is therefore the need to assess the current circulating status of H7N7 subtype equine influenza viruses in Nigeria, where a combination of absence routine vaccination, poor vaccine storage and lack of quarantine protocols could pose a serious problem of rapid antigenic drift of the viruses. This study was therefore designed to investigate if H7N7 subtype influenza virus is still circulating among polo horses in the country.

Eighty horses were randomly selected from across the country during the 2004 annual polo tournament in Lagos, southwestern Nigeria. The horses were distributed as follows; from the North: Kano 14; Kaduna 15 and Katsina 11 while from the South: Ibadan 12; Lagos 18 and Port-Harcourt 10. About $10 \mathrm{ml}$ of whole blood were collected via jugular venipuncture from each animal into plain universal bottle. Collected samples were mixed up and transported to the laboratory on ice pack and allowed to clot overnight. Sera were harvested and clarified by centrifugation in a bench top Denley centrifuge and stored in $2 \mathrm{ml}$ aliquots at $-20^{\circ} \mathrm{C}$ until analyzed. Nasopharyngeal swabs were also obtained from forty horses and placed in Hanks balanced salt solution (HBSS) medium and stored at $-4^{\circ} \mathrm{C}$ until analyzed.

Influenza A viral antigens (A/eq/Sao Paulo/76 [H7N7] and A/eq/Connought Detroit/64 [H7N7]) and control antiserum were obtained from Professor Adeyefa's repository, in the Department of Veterinary Medicine, University of Ibadan while embryonated eggs and African green monkey kidney (Vero) monolayer cells were obtained respectively from Ajanla Hatcheries Nigeria Limited and WHO Collaborative Centre for Influenza, Centres for Disease Control and Prevention, Georgia, USA through the Department of Virology, College of Medicine, University of Ibadan, Ibadan, Nigeria. 
$\mathrm{HI}$ and VN tests and virus isolation in embryonated hen eggs and tissue culture were carried out on test sera and nasopharyngeal swabs respectively according to the WHO standard using $1 \%$ turkey red blood cells (rbc) as indicator for $\mathrm{HI}$ and foetal calf serum as control for VN (CDC 1981; Olaleye et al., 1990; Adeniji et al., 1993; Olusa \& Adeyefa, 2009).

The $\mathrm{HI}$ titre for the control antiserum used in the $\mathrm{HI}$ test was 640 while the $\mathrm{HI}$ titres of the test sera ranged from 40-20,480. Fourteen samples (35\%) had $\mathrm{HI}$ titres between 40 and 320 while eighteen samples (45\%) were from 640-2,560. Seven samples $(17.5 \%)$ had antibodies levels of $5,120-20,480$ and only one sample (2.5\%) was negative.

Cytopathic effect (CPE) was found in the Vero monolayer cells for thirty-three samples (82.5\%) and the dilution at which CPE was observed was determined to be the neutralization titre. Neutralizing antibodies were not found in seven samples (17.5\%). Viral isolation in embryonated hen eggs from the nasopharyngeal swabs was negative. None of the paired allantoic fluid harvested from the two control eggs was positive on haemagglutination test.

The presence of high $\mathrm{HI}$ and neutralizing antibodies in the test population is an indication of continuous exposure of the polo horses to $\mathrm{H} 7$ subtype of influenza viruses. In Nigeria, horse grooms and handlers keep local chickens/chicken feeds, ducks and other domestic animals in polo stables and horse that attract feral birds which could serve as a source of exposure for the horses. Since no equine $\mathrm{H} 7$ virus was isolated from the sterile swabs collected at the time the horses were bled for sera, it is not known with certainty whether the $\mathrm{H} 7$ viruses were of equine or avian origin. The horses might have been exposed to either a low pathogenicity equine $\mathrm{H} 7$ subtype virus or the highly/lowly pathogenic avian influenza virus strains. This should not be unexpected since avian influenza viruses are known to cross species barrier to infect new hosts (Horimoto \& Kawaoka, 2001). Most recently, HPAI H5N1 viruses infecting man and other species have been reported in Asia, Europe, Middle East and Africa (Chen et al., 2006; Normile, 2006; Salzberg, 2007; Monne et al., 2008). Moreover, Guo et al., (1992) reported the infection of horses in Southern China by novel avian H3N8 influenza virus to which the horses where naïve and which caused high mortality and serious economic losses.

In Nigeria, horses are generally not vaccinated routinely against equine influenza. Although some owners who travel abroad occasionally purchase and administer influenza vaccines (Adeyefa \& McCauley, 1994), the high antibody titres observed in this study cannot be accounted for by the low proportion of vaccinated horses if any as at the time of sampling. Moreover, immunity would wane after vaccination if there is no virus challenge (Adeyefa \& McCauley, 1994). Although it is probable that the high antibody titres reported here may confer some degree of protection on these valuable horses, this may be short lived in view of antigenic variation and reassortment of genes common with two different influenza viruses (Wiley et al., 1981; Skehel et al., 1984; Adeyefa et al., 1994; Horimoto \& Kawaoka, 2001; Monne et al., 2008). It is our opinion that the horses sampled were exposed to low pathogenicity equine or avian influenza viruses which may still be circulating among these horses.

Influenza is an economically important disease of horses as well as other host species. And in the light of its potential for rapid global spread and propensity for interspecies, continuous surveillance, both passive and active and emergency preparedness plans should be established globally and in Nigeria in particular to forestall the serious economic impact of the disease. This is very pertinent in view of the recent HPAI H5N1 outbreaks and the most recent new 2009 swine origin H1N1 pandemic virus (Chen et al., 2006; Normile, 2006; Ducatez et al., 2007; Garten et al., 2009; Smith et al., 2009). Further studies are recommended in order to isolate and characterize $\mathrm{H} 7$ influenza viruses from equine and avian host species which may prove to be pathogenic to horses. These could then be incorporated into currently available commercial vaccines for horses. Further studies are also required to determine host and viral factors responsible for interspecies transmission and the horses' immunological responses to influenza $A$ virus invasion.

\section{REFERENCES}

Adeyefa, C. A. O \& McCauley, J. W. (1994). Outbreak of equine influenza in Polo horses in Ibadan, Nigeria: Virus isolation, clinical manifestation and diagnosis. Veterinary Records, 134: 683-684.

Adeyefa, C. A. O., Quayle, K. \& McCauley, J. W. (1994). A rapid method for the analysis of influenza virus genes: application to the reassortment of equine influenza virus genes. Virus Research, 32 : 391-399.

Adeyefa, C. A. O. (1995). Molecular and antigenic characterization of influenza viruses isolated from horses in Nigeria. PhD Thesis, University of Ibadan, Nigeria.

Adeyefa, C.A.O., Hamblin, C., Cullinane, A., \& McCauley, J. W. (1996a). Nationwide serological survey of equine influenza in Nigeria. Revue d'Elevage et de Medecine Veterinaire des Pays Tropicaux, 49 (1): 27-29

Adeyefa, C. A.O., James, M. L., \& McCauley, J. W. (1996b). Antigenic and genetic analysis of equine influenza viruses from tropical Africa in 1991. Epidemiology and Infection, 117: 367-374

Adeyefa, C. A. O \& McCauley, J. W. (1997a). Direct sequencing of influenza A virus RNAs from clinical samples. Tropical Veterinarian, 15: 67-72

Adeyefa, C. A. O., McCauley, J. W., Danefi, A. I., Kalejaiye, O.A., Bakare, A., \& Ashimolowo, O. (1997b). Cellular immune recognition of influenza A viruses in horses: in-vtro and in-vivo, studies on the immunogenicity of influenza a viruses in equines. Acta Veterinaire. Brno 66: 39-49

Adeyefa, C. A. O., McCauley, J. W. \& Tomori, O. (2000). Antigenic variation among Nigerian strains of equine-2 influenza viruses. Veterinary Archive 70(3):113-120

Adeniij, J. A., Adu, F. D, Baba, S. S, Ayoade, G. O, Owoade, A. A. \& Tomori, O. (1993). Influenza A and B antibodies in pigs and chicken population in Ibadan metropolis, Nigeria. Tropical Veterinarian, 11: 39-45.

Anastaad, G. O. \& Maagaard, O. (1990). Rapid diagnosis of equine influenza. Veterinary Records, 126: 550-551

Bayly, W. M. (1998). Respiratory diseases of horses: Equine Influenza. In: Aiello S.E. (ed): Merck Veterinary Manual. Merck \& Co. Inc. Philadelphia, USA

Bourn, D. (1992). Highlight of the Nigerian livestock resources report. Nigerian livestock resources. Environmental Research Group. Oxford Ltd. Oxford, UK

Center for Disease Control (CDC). (1981). Center for Infectious Diseases, WHO Collaborating Center for Influenza, USA. The Haemagglutination inhibition test for influenza viruses 1-21 
Chen, H., Li, Y., Li, E., Shi, J., Shinya, K., Deng, G., Qi, Q., Tian, G., Fan, S., Ehao, H.,San, Y \& Kawaoka, Y. (2006). Properties and dissemination of $\mathrm{H} 5 \mathrm{~N} 1$ viruses isolated during an influenza outbreak in migrating waterfowl in western China. Journal of Virology 80(12): 5976-5983

Ducatez, M. F., Olinger, C. M., Owoade, A. A., Tamagda, Z., Tahita, M. C., Sow, A., deLandrshear, S., Ammervan, W., Qnedraego, J. B., Orerhaus, A. D. M., Fouchier, A. M \& Muller, C. P. (2007). Molecular and antigenic evolution and geographical spread of H5N1 highly pathogenic avian influenza viruses in Western African. Journal of General Virology, 88 (8): 2297-2306

Dulbecco, R. \& Gunsberge, H. S. (1988). Virology $2^{\text {nd }}$ ed. J.B Lippincott Company, Philadelphia

Easterday, B. C. (1975). Animal influenza. In: Kilbourn E.D ed. The influenza viruses and influenza. Orlando academic press

FAO: (2008). Nigeria/liveanimal/horse/stock. FAOSTAT division. www.fao.org. Accessed May, 2010

Garten, R. J., Davis, T., Russel, C. A., Shu, B., Lindstron, S., Balish, A., Sessions, W.M., Smith, D. J., Klimon, A. I \& Cox, N. J. (2009). Antigenic and genetic characteristics of swine origin 2009 A (H1N1) influenza viruses circulating in humans. Science, 1126: $2-10$

Guo, Y., Jin, F., Wang, P., Wang, M., \& Zhu, J. (1983). Isolation of influenza $C$ virus from pigs and experimental infection of pigs with influenza C virus. Journal of General Virology, 64: 177-182

Guo, Y., Wang, M., Kawaoka, K., Gorman, O., Ito, T., Saito, Y., \& Webster, R.G. (1992). Characterization of a new avian like influenza A virus from horses in China. Virology, 181: 245-255

Guo, Y., Wang, M., Zheng, G. S., Li, W., Kawaoka, K., \& Webster, R. G. (1995). Seroepidemiological and molecular evidence for the presence of two H3N8 equine influenza viruses in China in 199394. Journal of General Virology, 76:

2009-2014

Horimoto, T \& Kawaoka, V. (2001). Pandemic threat posed by Avian influenza A viruses. Clinical Microbial Review, 14 (1): 129149

Knight, V. (1973). Airborne transmission and pulmonary deposition of respiratory viruses. In: Hers, J.F and Winkler, K.C eds. Airborne transmission and airborne infection. Wiley. New York

Lai, A. C., Lin, V. P., Powel, D. G., Shortridge, K. F., Webster, R. G., Daly, J., \& Chambers, T. M. (1994). Genetic and antigenic analysis of the influenza virus responsible for the 1992 Hongkong equine influenza epizootic. Virology, 204 (3): 673-679
Monne, I., Joannis, T. M., Fusaro, A., DeBenedickia, P., Lombin, L. $\mathrm{H}$ \& Ularama, O. (2008). Reassortant avian influenza (H5N1) in poultry in Nigeria. Emerging Infectious Diseases, 14(4): 637-640

Murphy, B. R. \& Webster, G. R. (1996). Orthomyxoviruses. In: Fields, B.N., Knipe, D.M and Howley, P.M eds. Fields Virology. $3^{\text {rd }}$ edn. Lippincott-Raven, Philadelphia, USA. 1397-1445

Normile, D. (2006). Avian influenza: Europe sramble to control deadly H5N1 strain. Science, 310(5474): 417

Olaleye, O. D., Omilabu, S. A., Baba, S. S and Fagbami, A. H. (1990). Haemagglutination-inhibiting $(\mathrm{HI})$ antibodies against strains of influenza A virus in horse and pig sera in Nigeria. Journal of Hygiene Epidemiology Microbiolgy and Immunology, 34 (4):365370

Olusa, T. A. O \& Adeyefa, C. A. O. (2009). Serosurveillance of equine $\mathrm{H} 3$ influenza virus in horses in Ibadan, Nigeria. Tropical Veterinarian, 27(2): 15-19

Salzberg, S. L. (2007). Genome analysis linking recent European and African influenza H5N1 viruses. Emerging Infectious Diseases, 13(5):713-718

Skehel, J. J., Stevend, D. J., Daniels, R. S., Douglas, A. R., Knossow, M., Wilson, I. A \& Wiley, D.C. (1984). A carbohydrate side chain of haemagglutinins of Hong Kong influenza viruses inhibits recognition by a monoclonal antibody. Proceeding of National Academy of Science. USA. 81:1779-1783

Smith, G. J. D., Vijaykrishna, D., Bahl, J., Lyceth, S., Worobey, M., Pybab, O. G., Ma, S. K., Chang, C. M., Raghwani, J., Bhatt, S., Peiris, J. S. M., Guan, Y \& Rambaut, A. (2009). Origin and evolutionary genomics of the 2009 swine origin H1N1 influenza A epidemic. Nature letters, 459: 1122-1126

Webster, R. G., Bean, W. J., Gorman, O. T., Chambers, T. M \& Kawaoka, Y. (1992). Evolution and Ecology of influenza A viruses. Microbial Review, 56: 152-179

Webster, R. G. (1993). Are equine viruses still present in horses? Equine Veterinary Journal, 25: 537-538

Wiley, D. C., Wilson, I. \& Skehel, J. (1981). Structural identification of the antibody-binding sites of Hong Kong influenza haemagglutinin and their involvement in antigenic variation. Nature, 289: 373-378

Wood, J. \& Mumford, J. (1992). Epidemiology of equine influenza. Veterinary Records, 130 (2) 126

Wright, P.V.F., Neumann, G \& Kawaoka, Y. (2007). Orthomyxoviruses. In: Field Virology. $5^{\text {th }}$ edition $1691-1740$ 